\title{
The Impact of Complaints' Handling on Customers' Satisfaction: Empirical Study on Commercial Banks' Clients in Jordan
}

\author{
Mohammad Z. Shammout ${ }^{1} \&$ Shafig I. Haddad ${ }^{2}$ \\ ${ }^{1}$ Applied Science University, Amman, Jordan \\ ${ }^{2}$ Vice President and Dean of Scientific Research \& Graduate Studies, Applied Science University, Amman, \\ Jordan \\ Correspondence: Shafig I. Haddad, Vice President and Dean of Scientific Research \& Graduate Studies, Applied \\ Science University, Amman, Jordan. E-mail: beroboshtoto@gmail.com
}

Received: August 13, 2014

Accepted: September 22, 2014

Online Published: October 25, 2014

doi:10.5539/ibr.v7n11p203

URL: http://dx.doi.org/10.5539/ibr.v7n11p203

\begin{abstract}
This study aims at identifying the most important impacts of complaints' handling on customers' satisfaction in the commercial banks' in Jordan, also aims to provide recommendations and suggestions to the top managements to handle customers' complaints in order to enhance customers' satisfaction.

The sample of the study consists of five commercial banks in Jordan (Housing Bank, Arab Bank, Bank of Jordan, Cairo Amman Bank And Ahli Bank) of 419 questionnaires were distributed in several phases until 384 questionnaires have been confirmed. Complaints' handling was the main domain of the study as the dependent variable and consists of six dimensions which are considered to be the sub independent variables for the purpose of the study (service recovery, service quality, switching cost, service failure, service guarantee and perceived value) and the dependent variable was customer satisfaction.

The results of the research showed that there is a statistically significant impact of the overall dimensions of complaint handling (service recovery, service quality, switching cost, service failure, service guarantee, and perceived value) on customer satisfaction.
\end{abstract}

Keywords: complaint handling, customers' satisfaction, commercial banks, Jordan

\section{Introduction}

The first law of service quality and productivity is: do it right the first time, but organizations can't ignore the fact that failures continue to occur, sometimes for reasons outside the organization's control (Lovelock \& Wirtz, 2011), currently, banks are concentrating on satisfying customers from their unique services (Hasan et al., 2011).

According to the aforesaid, customer satisfaction cannot be achieved without the fundamental contribution of the customer contact-employees who provide the service. Thus, front-line employees should stay focused on customers' needs (Aburoub et al., 2011).

Studies show that the majority of complaints are made at the place where the service was received, past research developing and implementing a customer feedback system and found that more than 99 percent of customer feedback was given face to face or over the phone to customer service representatives. Less than (1) percent of all complaints were submitted via email, letter, customer feedback cards, or the firms' website (Lovelock \& Wirtz, 2011).

Therefore, with the growing concern of the banks to deliver the best service has encouraged the researcher to study the impact of complaints' handling on the banks customers' satisfaction.

\subsection{Problem of the Study}

The problem of this study is related to personal mistakes by the employees; which might be caused by lack of adequate training had been given to frontline staff, lack of experience and inability to meet customer requests efficiently. These problems fundamentally affect customer satisfaction towards the quality of banking services in Jordan, and the way of handling such these problem (Forbes Middle East, 2013).

In order to maintain high customer satisfaction, management of the commercial banks in Jordan must 
concentrate on handling the complaints' of the customers' right up from the first time.

The problem of the study can be stem from the following question:

What is the impact of complaints' handling (service recovery, service quality, switching cost, service failure, service guarantee, and perceived value) on customers' satisfaction in the commercial banks in Jordan?

\subsection{Importance of the Study}

The importance of this study is summarized in the following points:

1) To highlight the significant role played by commercial banks in Jordan in handling customers' complaints in order to develop and increase the effectiveness of commercial banks in terms of its impact on customer satisfaction, In addition to the policies followed by the bank in the process of receiving and handling the customers' complaints in order to improve and develop the quality of banking services in Jordan through finding creative and innovative methods to solve customers' problems in an effective manner.

2) Highlighting the importance of effective handling customer's complaints by Jordanian banks in order to avoid similar cases in the future, and attaining customer's satisfaction.

3) Recognizing the importance of customers' satisfaction in order to achieve a competitive advantage for the banking sector in Jordan.

4) This study comes to highlight the issue of handling customers' complaints in order to enhance the service perceived value by the customer and provide a suitable climate for customers to get a good service.

5) To know the importance of service recovery in order to achieve customer satisfaction.

6) To entitle The importance of the banking sector in Jordan, where the number of total banks is 26 , while the number of commercial banks is 16 banks, with total branches of 702 within Amman city as it holds $62.8 \%$ of the total number of branches in Jordan, with total assets of 36.1 billion JD, 27.3 billion JD goes to commercial banks. The number of ATM machines is 1219 , while the total number of employees is 17347 according to the annual report of the Association of Banks in Jordan thirty-third in 2011.

\subsection{Objectives of the Study}

The objectives of this study are as follows:

1) To identify the highest dimensions of impact in complaint handling on customer satisfaction in the commercial banks in Jordan.

2) To provide recommendations and suggestions to the top managements of commercial banks in Jordan to handle customers' complaints in order to enhance customers' satisfaction.

\subsection{Model of the Study}

Based on the literature review of this study and the research objectives. The researcher proposes the model in Figure 1 that measures the impact of complaints handling as an independent variable on customer satisfaction as a dependent variable.

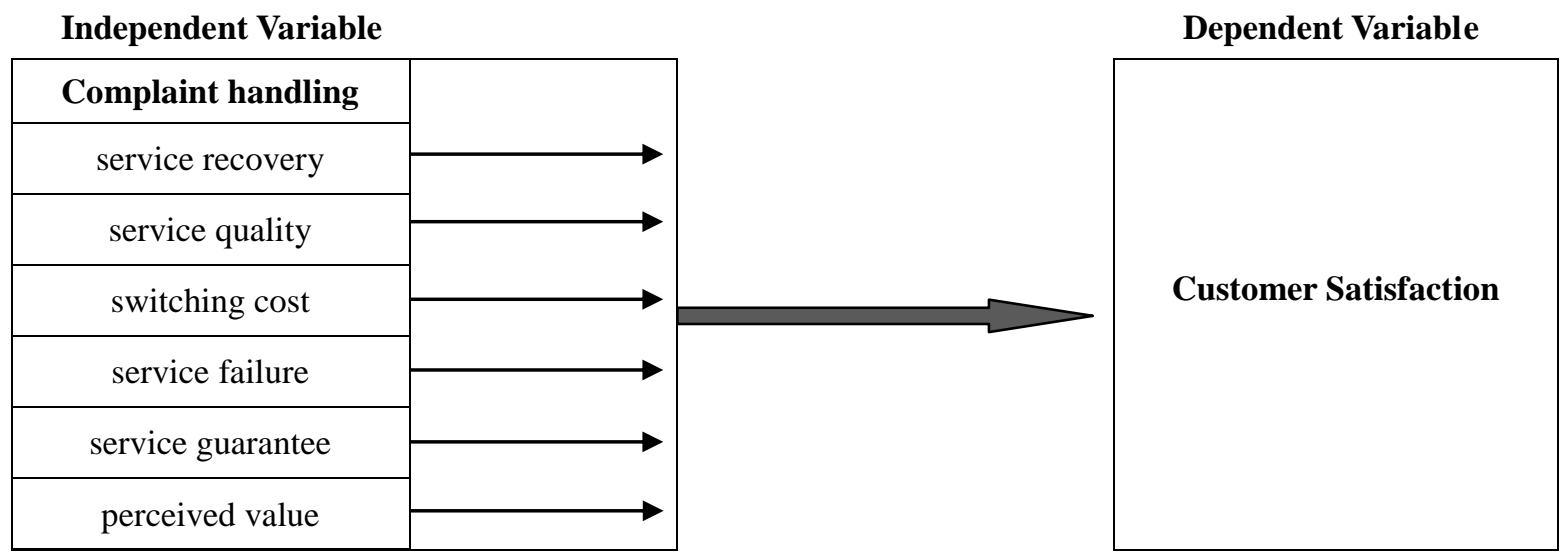

Figure 1. Model of the study

Source: This model prepared by the researcher based on these Sources (Johnston, 2001; Yang \& Peterson, 2004, Hays \& Hill, 2006; McCollough, 2009 ; Sadeh, Mousavi \& Sadeh, 2011; Rahman, Khan \& Haque, 2012; Boshoff, 2012). 


\subsection{Hypotheses}

Based on the main problem of the study and objectives, the researcher formulated the following hypotheses in a null form:

H01: there is no statistically significant impact of the overall collective dimensions of complaints' handling on customer satisfaction.

H011: there is no statistically significant impact of service recovery on customers' satisfaction.

H012: there is no statistically significant impact of service quality on customers' satisfaction.

H013: there is no statistically significant impact of switching cost on customers' satisfaction.

H014: there is no statistically significant impact of service failure on customers' satisfaction.

H015: there is no statistically significant impact of service guarantee on customers' satisfaction.

H016: there is no statistically significant impact of perceived value on customers' satisfaction.

\subsection{Operational Definitions}

\subsubsection{Independent Variables}

Complaint is a conflict between a client and a bank in which the fairness of the resolution procedures.

Service Recovery refers to the actions by a bank to restore a client to a state of satisfaction after a service failure and complaint.

Service Quality is a function of the differences between expectation and performance along the quality dimensions.

Switching Cost defined as the cost involved in changing from one bank to another.

Service Failure an exchange in which a client experiences a loss due to the failure.

Service Guarantee is a promise by a bank that they will perform at a certain level and, if that level is not met, the bank also promises to compensate the client in some way.

Perceived value: the client's overall assessment of the utility of a service based on what is received and what is given.

\subsubsection{Dependent Variable}

Customer's Satisfaction: the client's perception of the performance of the service in relation to his or her expectations.

\section{Theoretical Framework}

The Theoretical framework includes describing independent variables and dependent variables and its components.

\subsection{Complaints' Handling}

It is one of the essential pillars of customer service, customer retention and customer delight, and it's a smart business to understand why customers complain, so you can stop complaints from happening in the first place. Understanding why customers complain, and addressing concerns before they happen might save time (customerservicezone.com, 2006).

\section{What Consumers Are Complaining About?}

Almost half of consumers' complaints about banking services relate to opening, closing or managing their accounts. Another quarter of complaints are about deposits and withdrawals. Problems in this category include transaction holds and unauthorized transactions. Difficulties caused by low funds, such as overdraft fees and bounced checks, are another significant complaint category. About $11 \%$ of consumers are frustrated with sending or receiving payments, and $6 \%$ have gotten fed up with trying to use their ATM or debit cards. The CFPB has forwarded $80 \%$ of consumers' complaints to the banks (another 15\% have been referred to different government agencies, and the rest were incomplete or require further action by the consumer). Banks have responded to $97 \%$ of the complaints they've received, and roughly $25 \%$ of customers received (Forbes, 2013).

Actions Banks Are Taking to improve their customer service: (Forbes, 2013).

\section{1) Monitoring social media}

Banks are looking for consumer complaints on Facebook and Twitter, then both responding to the consumer to 
address the issue and contacting bank staff to prevent the issue from reoccurring.

\section{2) Making it easier to be heard}

The CFPB's website has made it incredibly easy to file a complaint against a bank. Banks such as Bank of America, Key Bank and Ally are making it just as easy to be heard through their own websites. Customers no longer have to call and navigate finicky automated systems. Instead, they can email customer service or even chat instantly. These venues not only make it easier to complain directly to the bank, they also give customers a written record of who said what and when, which might come in handy if the complaint can't be resolved on the first try.

\section{3) Anticipating questions}

Banks are posting answers to frequently asked questions on their websites to help consumers solve problems on their own. Customers don't have to call customer service or visit a branch to find out how to check the status of a bill payment or how to make a wire transfer. Some banks, such as Ally, allow customers to instantly rate whether the answer to an FAQ was helpful. Banks can then use this feedback to provide better information.

\section{4) Implementing strong and clear processes}

Being able to monitor the frequency and types of complaints may cure or change an issue that a consumer is having without the need for regulatory intervention.

Not all banks are taking these actions, however, and even those that are can't reach every dissatisfied consumer (Forbes, 2013).

Research findings consistently show that as much as 85 percent of the variation in the satisfaction with a service recovery was determined by three dimensions of fairness: procedural justice, interactional justice, and outcome justice (Lovelock \& Wirtz, 2011).

\subsubsection{Service Recovery}

"It is a though-out process for returning aggravated customer to a state of satisfaction with the firm after a service or product has failed to live up to the customer's expectations".

Service failure takes place when the negative effects on profitability and customer loyalty create drastic challenges for service organizations to overcome (Zemke \& Bell, 1990).

\subsubsection{Service Quality}

(Allerd, 2001) states that the quality of service means to adapt with requirements, in other words service establishment should create specific requirements and specific services. The objective of making different jobs of organization of quality is the whole conformity of such jobs with specifications and requirements defined by the organization. Generally it is known that customers take into consideration many dimensions when evaluating service quality.

It is difficult for service organizations to put forward observation procedures to define standards of the quality of service provided to customers. Nevertheless (Kozub, 2008) refers to the existence of service quality ten dimensions as follow:

1) Credibility: means possibility of service provider obligations and if helshe is trustworthy

2) Responsiveness: readiness of service provider to achieve and perform service in accuracy and in a reliable manner.

3) Reliability: the ability of service provider to achieve and perform service accurately and in a reliable manner.

4) Security: it relates to degree of security and risk free.

5) Understanding: knowing the customers needs accurately.

6) Tangibles: to aspect of material facilities provided to the service organization such like (tools, supplies...etc).

7) Accessibility: the availability of service in place and time required by customer.

8) Courtesy: means service provider's high degree of respect and appreciation of customer feeling and dealing with them with affection.

9) Competence: service providers sharing skills and knowledge required.

10) Communication: when service provider is able to inform the beneficiary about nature of service provided and the role that beneficiary should play to obtain service required. 


\subsubsection{Switching Costs}

It defined as the sacrifices or penalties consumers feel they may incur in switching from one provider to another (Jones et al., 2007) while switching costs are associated with changing providers, they are not always incurred immediately upon switching.

(Burnham et al., 2003) developed a switching cost typology that identified three types of switching costs which are: Procedural switching costs, Relational switching costs, and financial switching costs.

(Jones et al., 2007) recently identified the dimensions of switching costs that are similar to those of (Burnham et al., 2003): Social switching costs, Procedural switching costs, and lost benefits costs. At the same time they argue that it is important to classify switching costs depends on the underlying nature of constraint involved. Negative and Positive switching costs. the researcher concludes that the social switching cost and lost benefit switching costs are related to positive switching costs, and procedural switching costs is related to negative switching costs.

\subsubsection{Service Failure}

To create and maintain satisfied customers, the primary goal of a service organization in the banking sector must be to operate to standard of quality and excellence; therefore, doing things right the first time (Lovelock \& Wirtz, 2011).

\subsubsection{Service Guarantee}

"Service guarantee is defined as a promise by a firm that they will perform at a certain level and, if that level is not met, the firm also promises to compensate the customer in same way" (Hays \& Hill, 2006).

\subsubsection{Perceived Value}

(Kozub, 2008) defined the perceived value as trade-off between the benefits and sacrifices. (Holbrook, 1994) confirms that consumer value is the transaction between customer and the product from which value results from. According to his research, consumer value consists of eight factors which are: excellence, efficiency, aesthetic, play, self-esteem, morality, spirituality and politics. (Sheth et al., 1991) identified five dimensions of the value which are: functional value, emotional value, social value, epistemic value, and conditional value.

Other researchers have identified and selected dimensions of perceived value by interviewing the consumers. (Sheth et al., 1991) developed a broader theoretical framework of consumer perceived value. Also he suggested five dimensions related to the perceived utility of a choice which are: functional value, emotional value, social value, epistemic value, and conditional value.

(Grewal et al., 1998) identified two additional dimensions of consumer perceived value, acquisition and transaction value.

According to (Kantamneni \& Coulson, 1996) they have identified four dimensions of a product perceived value, which are: market value, functional value, experiential value, and societal value.

\subsection{Customers' Satisfaction}

Customer satisfaction viewed as a response based on assessments and expressed some time during the buy-consumption process (Sunayana, 2013).

Customer satisfaction is the consequence of a number of both psychological and physical factors which associate with satisfaction behaviors (Uddin \& Akhter, 2012).

\section{Literature Review}

The study of (Naser, Jamal, \&AL-Khatib, 1999): Islamic banking: a study of customer satisfaction and preferences in Jordan.

The main objective of this study was to investigate the degree of customer satisfaction of a sample of an Islamic bank's customers, and attempt to evaluate the degree of customer awareness and satisfaction towards an Islamic bank in Jordan. A sample of 206 respondents took part in this study. The analysis of the questionnaire respondents showed a certain degree of satisfaction of most of the Islamic banks facilities and products. Also the respondents indicated that they are aware of specific Islamic financial products such like Murabaha Musharaka and Mudaraba. The researcher's findings indicate that majority of respondents were satisfied with most aspects of the Islamic bank's products and services.

\section{The study of (Johnston, 2001): Linking complaint management to profit.}

This study mentioned that complaint management should lead to operational improvement and improved 
financial performance should attain customer satisfaction. Many organizations ignore the operational value of complaints and as a result many complaint processes seem geared to trying to mollify customers rather than ensuring that problems do not reoccur. Using data from an empirical benchmarking study, based on a detailed questionnaire completed by customer service managers in 40 UK organizations, the relationships between seven key variables, complaint processes, satisfaction, retention, process improvement, employee attitude and retention, and financial performance are calculated and a relationship model developed. The results expose significant correlations between all variables in the model, as a result four acid tests of complaint management are proposed. It is suggested that financial improvements may be better leveraged by bringing about organizational improvements and by ensuring complaint processes are "staff-friendly", rather than simply trying to satisfy customers

The study of (Kerr, 2004): Service Recovery and the Elusive Paradox: An Examination of the Effects of Magnitude of Service Failure, Service Failure Responsiveness, Service Guarantee and Additional Recovery Effect on Service Recovery Outcomes.

This research contains two studies The purpose of the Study 1 is to know the effects of magnitude of service failure, service failure responsiveness, and the presence of a service guarantee on customer satisfaction levels and other service recovery outcomes; and the aim of study 2 is to identify the effects of additional recovery effort and magnitude of service failure on customer satisfaction levels and other service recovery outcomes. The results indicated several findings; Magnitude of service failure had a very strong individual and moderating influence on all outcome variables. Service failure responsiveness can have positive effects on these outcome variables. Service guarantee was found to have little effect on service outcomes.

The study of (Yang \& Peterson, 2004): Customer Perceived Value, Satisfaction and Loyalty: The Role of Switching Costs.

In this study the researchers investigated perceived value, satisfaction, loyalty and switching cost. A Web-based survey was used in the study. A solicitation letter was transmitted by e-mail to four thousands subjects randomly chosen from an e-mailing list provided by an e-mail broker, The responses from two hundred and fifty seven participants were forwarded to the leading author via e-mail of these, 22 were out because they were incomplete, so the effective sample size was 235 . The results, indicate that companies should focus primarily on satisfaction and perceived value. The findings suggest that customer loyalty can be obtain through improving customer satisfaction and offering high product/service value to satisfy online customers.

The study of (Rothenberger, Grewal \& Iyer, 2008): Understanding the Role of Complaint Handling on Consumer Loyalty in Service Relationship.

In this study the researchers explore the role of 5 drivers of loyalty: customer usage level, service pricing, service quality, membership in the firm's loyalty program, and satisfaction with complaint handling. The effects of these drivers may differ for customers who complain versus who do not complain. The questionnaire of this study was administrated to passengers of a major European airline. On randomly selected routes between Germany, Austria, and Switzerland, passengers is randomly selected flights and seat numbers received questionnaires with total amount of two thousands and six hundreds. The researchers found that the satisfaction with complaint handling was key to consumer recommendation of the service to others.

The study of (McCollough, 2009): The Recovery Paradox: The Effect of Recovery Performance and Service Failure Severity on Post-Recovery Customer Satisfaction.

In this study the researchers investigated the recovery paradox, the proposition that superior recovery can leave the customer as satisfied, if not more satisfied, than if nothing had gone wrong by examining the impact of service failure severity and the recovery performance on post-recovery satisfaction. Passengers from 50 departures were included in the sample, and all carriers were represented by several departures. In total, 237 passengers were approached and asked to participate in this study. The researcher suggests that the greater service failure severity the greater the recovery performance necessary to convert the customers' dissatisfaction into satisfaction and the more difficult it should be for the service provider to achieve full recovery. Results show that service failure severity must be very modest and the recovery effort must be superior.

The study of (Alvarez, Casielles, \& Martin, 2011): Analysis of the Role of Complaint Management in the Context of Relationship Marketing.

This research aims to contribute to the relationship-marketing strategy by studying the role of complaint management in long-term relationships. The findings confirm the importance that theory accords to the relationship-marketing strategy, and also provide evidence for the importance of complaint management. Thus 
having a good complaint-handling system and trained and motivated staff who are fully committed to the firm's objectives are fundamental requisites for firms to be able to build a stable customer portfolio.

The study of (Wu, 2011): Customer Loyalty Explained by Electronic Recovery Service Quality: Implications of the Customer Relationship Re-Establishment for Consumer Electronics E-Tellers.

This study related to examine and explore the relationships among electronic service quality, customer satisfaction, electronics recovery service quality, and customer loyalty for consumer electronics e-tellers. Results indicated that e-recovery service quality had positive effect on customer loyalty, and electronic recovery service quality had no effect on perceived value and customer satisfaction. Findings also indicated that perceived value and customer satisfaction were two significant variables that mediated the relationships between e-service quality and customer loyalty.

The study of (Sadeh et al., 2011): The Structural Model of E-service Quality, E-customer Satisfaction, Trust, Customer Perceived Value and E-loyalty.

The aim of this study is to asses' causal linkages among e-service quality, e-customer satisfaction, trust, customer perceived value and e-loyalty and present a structural model under causal effect technique.

The results indicate e-loyalty is the most significant variable in online retailing which receives the most influences from other variables. Also, the results reveal that privacy, fulfillment and efficiency were the most effective dimensions in the e-retailing system.

The study of (Alshurideh et al., 2012): The Effect of Customer Satisfaction upon Customer Retention in the Jordanian Mobile Market: An Empirical Investigation.

This study aimed to ascertain the extent to which customer satisfaction affects Customer retention among the major three cellular phone companies in the three Jordanian Mobile companies (Zain, Orange and Umnia). In this study the researchers found that customer satisfaction affect customer retention in the Jordanian mobile behavior setting, and also found a direct relationship between customer-supplier relationship duration and customer satisfaction.

The study of (Rahman et al., 2012): A Conceptual Study on the Relationship between Service Qualities towards Customer Satisfaction: Servqual and Gronroos's Service Quality Model Perspective.

The aim of this research is to identify the effect of service quality on customer's satisfaction under the perspective of SERVQUAL and Gronroos service quality model. The factors of this study are customer expectations of the service, customer participation, the image and reputation of the service organization, aspects of the service setting and the actual service encounter.

The study of (Chuang et al., 2012): The Effect of Service Failure Types and Service Recovery on Customer Satisfaction: A Mental Accounting Perspective.

This study reports the finding of two studies, draws on mental accounting theory to examine the effect of the relationship between service failure and service recovery on customer satisfaction. The results of Study 1 show that customer satisfaction is greater when service recovery efforts truly make up for what customers have lost. The findings of Study 2 indicate that the magnitude of a service failure also has an impact on the effectiveness of service recovery efforts. The sample of the study is a non-student sample comprising 62 men and 82 women with an average age of 33.7 was also recruited from university in southern Taiwan. This study suggests that service firms should formulate failure recovery strategies and engage in appropriate recovery efforts that meet the real needs of customers.

The study of (Lee, 2013): Major Moderators Influencing the Relationships of Service Quality, Customer Satisfaction and Customer Loyalty.

In this study the researcher investigates the service quality, customer satisfaction, and customer loyalty of mobile phone users in Korea. The results of the study showed that service quality and customer satisfaction had a positive effect on customer loyalty, and service quality also influences customer satisfaction positively. While, customers with high perceived service quality and satisfaction have strong loyalty. The study showed that fact moderating variables positively influence the relationships among the aforementioned factors:

\section{What distinguishes this study from other studies?}

Some of the reasons that make this study unique are:

1) The lack of studies that conducted on complaints' handling in the Jordanian society.

2) This study consist most factors of complaints' handling. 
3) This study is trying to investigate in complex and complicated issues which are the customer's satisfaction.

4) This study included and discussed most variables of complaint handling while the other studies take one or few variables and also this study focuses on the commercial banks in Jordan.

\section{Method}

\subsection{Study Population and Sample}

The population of the study is being represented by the clients of commercial banks in Amman, since the majority of the banks are located in the capital of Jordan, accordingly, the researcher has limited the required sampling frame by selecting the banks holding the largest number of branches, 50 branches and above, according to (Uma Sekaran, 2009) if the population size is bigger than 222640, the sample size will be 384 , so the researcher proposed the Table 2 that shows the distribution of the clients by the banks as seen in the table. accordingly the unit sample will be represented by the clients who post complaints about banking services in selected banks Based on the question "Have you experienced any conflict or problem in your bank services?", the sample will be confirmed.

Incident sample will be used in this study. According to (Malhotra, 2010) the respondents are selected, because they happen to be in the right place at the right time.

Table 1. No. of branches by the banks

\begin{tabular}{lc}
\hline Bank name & Branches number inside Jordan \\
\hline The Housing Bank for Trade \& Finance & 106 \\
Arab Bank & 79 \\
Bank of Jordan & 67 \\
Cairo Amman Bank & 66 \\
Jordan Ahli Bank & 50 \\
Total & $\mathbf{3 6 8}$ \\
\hline
\end{tabular}

Source (Abj, 2011).

Table 2. Distribution of the clients by the banks

\begin{tabular}{lc}
\hline Bank name & Number of clients * \\
\hline The Housing Bank for Trade \& finance & 111 \\
Arab Bank & 82 \\
Bank of Jordan & 70 \\
Cairo Amman Bank & 69 \\
Jordan Ahli Bank & 52 \\
Total & $\mathbf{3 8 4}$ \\
\hline
\end{tabular}

*Number of clients calculated based on the Formula:

Number of clients $=($ Branches number inside Jordan $\div$ total Branches number $) X(384)$

Table 3. Number of distributed, accepted and the frequency of the questionnaires by the banks

\begin{tabular}{lccc}
\hline Bank name & No. of distributed questionnaires & No. of accepted questionnaires & Frequency percentage \\
\hline The Housing Bank for Trade \& Finance & 121 & 111 & $91.73 \%$ \\
Arab Bank & 90 & 82 & $91.11 \%$ \\
Bank of Jordan & 78 & 70 & $89.74 \%$ \\
Cairo Amman Bank & 74 & 69 & $93.24 \%$ \\
Jordan Ahli Bank & 56 & 52 & $92.85 \%$ \\
Total & 419 & 384 & $91.6 \%$ \\
\hline
\end{tabular}




\subsection{Data Collection}

\subsubsection{Instruments of the Study}

Primary data: The data will be collected from respondent through the questionnaire that will be used later.

Based on literature, the questionnaire was developed by the researcher to collect data from the sample of the study, it's divided to three main parts; the first part is about demographic variables such as (age, gender, nationality, marital status, level of education and bank name), the second part is related to the independent variables questions, and the third part is about the dependent variable, that's in addition to the key question to figure out and include only those who experienced any problem with the banks under study.

Secondary data: the data will be collected through (books, articles, journals, websites, and also case studies) referred to the study.

\subsubsection{Measurement Scale}

Likert five scales will be applied in asking the questionnaire and measuring the study variables which is organized as strongly disagree to strongly agree and which takes the weight of (1-5).

The current study will use different scale to measure the main variables (independent and independent variables), scales will be used to measure the study constructs are drawn from the valuable literature, and are outlined in the following Table 4:

Table 4. Supported literature for measurement scale

\begin{tabular}{|c|c|c|}
\hline Variables & Supported literature & Variable measurement \\
\hline \multicolumn{3}{|l|}{ Independent variable } \\
\hline Service recovery & $\begin{array}{l}\text { Adopted from Kerr, 2004; McCollough, 2009; Wu, 2011; } \\
\text { Chuang, et al., } 2012\end{array}$ & Measured by questions 1-5 In the questionnaire \\
\hline Service quality & $\begin{array}{l}\text { Adopted from Rothenberger, Grewal\& Iyer, 2008; Wu, 2011; } \\
\text { Sadeh, et al, 2011; Rahman, Khan, \& Haque, 2012; Lee. } 2013\end{array}$ & Measured by questions 6-10 In the questionnaire \\
\hline Switching cost & Adopted from Johnston, 2001; Yang \& Peterson, 2004; Lee. 2013 & Measured by questions 11-16 In the questionnaire \\
\hline Service failure & $\begin{array}{l}\text { Adopted from Kerr, } 2004 \text {;McCollough, 2009; Chuang, et al., } \\
2012\end{array}$ & Measured by questions 17-21 In the questionnaire \\
\hline Service guarantee & Adopted from Kerr, 2004; Yang \& Peterson, 2004 & Measured by questions $22-26$ In the questionnaire \\
\hline Perceived value & $\begin{array}{l}\text { Adopted from Yang \& Peterson, 2004; Wu, 2011; Sadeh, et al, } \\
\text { 2011; Lee. } 2013\end{array}$ & Measured by questions 27-30 In the questionnaire \\
\hline \multicolumn{3}{|l|}{ Dependent variable } \\
\hline Customer satisfaction. & $\begin{array}{l}\text { Adopted from Naser, Jamal, \&AL-Khatib, 1999; Johnston, 2001; } \\
\text { Wu, 2011; Sadeh, et al, 2011; Alshurideh, Masa'deh and Alkurdi, } \\
\text { 2012; Rahman, Khan, \& Haque, 2012; Lee. } 2013\end{array}$ & Measured by questions $31-37$ In the questionnaire \\
\hline
\end{tabular}

\subsection{Validity of the Study}

Validity for the questionnaire was evaluated from four members of the marketing department from Applied Science Private University and one member of the marketing department from Mu'ta University and some of the questions were modified or deleted.

\subsection{Reliability of the Study}

Study Reliability was calculated by using test pre-test method, in which the researcher applies the study tool on a sample of 50 customers of the sample, after three weeks the same sample was tested again, the stability degree was $90 \%$ by using stability test; Cronbach's alpha technique was used for this purpose, and it's value for all of the domains was $(0.860)$ as shown in Table 5: 
Table 5. Reliability analysis for the study domains

\begin{tabular}{lc}
\hline The Domain & Cronbach's Alpha \\
\hline Over all dimensions & 0.860 \\
Complaint handling & 0.864 \\
Customers satisfaction & 0.912 \\
\hline
\end{tabular}

Source: This table was developed based on SPSS analysis.

\subsection{Data Analysis Tools}

A) The tools of describing and diagnosing the study variables:

- Frequency: used to review the study sample answers;

- Percentages: show the proportion of answers for a particular variant of the total answers;

- Mean: displays the average answers to a particular variable;

- Standard Deviation: shows the degree of dispersion of the answer from its mean.

B) Tools Used to Test Hypotheses:

- Simple regression: used to find the impact of the independent variable on the dependent variable;

- T test: used to find significant differences between the means of the variables of the study.

\section{Study Sample Characteristics}

The study sample characteristics analysis in Table 6 showed that the male were 214 and female 170, and also showed that most respondents are between 18 to less than 30 years old, and the highest marital status respondents were unmarried, and in the education section the bachelor degree got the highest number of respondents, the highest respondents were housing bank, and that most respondents experience years in the banking are less than 3 years.

Table 6. Frequency \& percentage of sample subjects in terms of age, gender, marital status, education, and banking experience

\begin{tabular}{lcc}
\hline Variables & Frequency & Percent \\
\hline Age & 240 & \\
18 to less than 30 & 71 & 62.5 \\
30 to less than 40 & 35 & 18.5 \\
40 to less than 50 & 20 & 9.1 \\
50 to less than 60 & 18 & 5.2 \\
60 and above & $\mathbf{( 4 8 4 )}$ & 4.7 \\
Total & & $(\mathbf{1 0 0})$ \\
Gender & 214 & \\
Male & 170 & 55.7 \\
Female & $(\mathbf{3 8 4})$ & 44.3 \\
Total & Frequency & $(\mathbf{1 0 0})$ \\
Marital status & 108 & Percent \\
Married & 276 & 28.1 \\
Unmarried & $(\mathbf{3 8 4})$ & 71.9 \\
Total & & $(\mathbf{1 0 0})$ \\
\hline
\end{tabular}




\begin{tabular}{lcc}
\hline Level of Education & Frequency & Percent \\
High school and less & 46 & 12 \\
Bachelor Degree & 264 & 68.8 \\
High Education & 74 & 19.3 \\
Total & $\mathbf{( 3 8 4 )}$ & $(\mathbf{1 0 0})$ \\
Bank Name & Frequency & Percent \\
Housing bank & 111 & 28.9 \\
Arab bank & 82 & 21.4 \\
Jordan bank & 70 & 18.2 \\
Cairo Amman bank & 69 & 18 \\
Ahli bank & 52 & 13.5 \\
Total & $\mathbf{( 3 8 4 )}$ & $(\mathbf{1 0 0 )}$ \\
Experience & Frequency & Percent \\
Less than 3 years & 147 & 38.5 \\
3-6 years & 132 & 34.4 \\
7-10 years & 33 & 8.6 \\
More than 10 years & $\mathbf{7 2}$ & $\mathbf{1 0}$ \\
Total & $\mathbf{( 3 8 4 )}$ & \\
\hline
\end{tabular}

Source: This table was developed based on the SPSS analysis.

\subsection{Description of Study Variables}

The researcher used the interval scale method based on Likert's Five-Point scale which is ranged from (1) Point, (strongly disagree). (2) Points, (disagree). (3) Points, (neutral). (4) Points, (agree). (5) Points, (strongly agree) according to this formula: $5-1 / 5=0.8$.

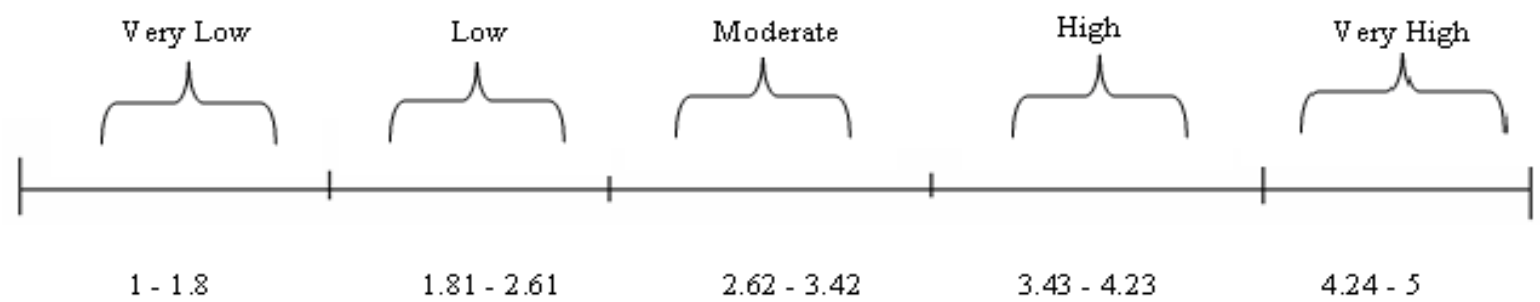

Figure 2. Response scale

Table 7. Response scale

\begin{tabular}{cc}
\hline Scale & Rate \\
\hline $1-1.8$ & Very Low \\
$1.81-2.61$ & Low \\
$2.62-3.42$ & Moderate \\
$3.43-4.23$ & High \\
$4.24-5$ & Very High
\end{tabular}

Also the researcher computed the means for all domains, as shown in Table 8 below: 
Table 8. Means and standard deviations for the whole study variables

\begin{tabular}{lccc}
\hline Item & Mean & Std. Deviation & Degree of Agreement \\
\hline Complaints' handling & 3.30 & .66607 & Moderate \\
Service recovery & 3.2792 & .93707 & Moderate \\
Service quality & 3.4359 & .87475 & High \\
Switching cost & 3.3950 & .66903 & Moderate \\
Service failure & 3.4536 & .81624 & High \\
Service guarantee & 3.1323 & .89092 & Moderate \\
Perceived value & 3.1283 & .96071 & Moderate \\
Customer satisfaction & 3.4676 & .88185 & High \\
\hline
\end{tabular}

Source: This table was developed based on the SPSS analysis.

From the previous Table 7 the grand mean for the domain variables were from (3.12) to (3.45), which service failure got the highest mean (3.45) and standard deviation of (.81624),the second rank was service quality with the mean of (3.43) and standard deviation (.87475). Also the table showed that the perceived value was of (3.12) and standard deviation of (.96071) and was the lowest mean.

\section{Complaints' handling}

The analysis indicated that the mean for the domain of complaints handling was (3.30) and standard deviation (.66607).

\section{Customers' satisfaction}

The analysis illustrated that the mean for customer satisfaction was (3.4676) and standard deviation (.88185).

\subsection{Testing the Study Hypotheses}

The researcher will test the study hypotheses and answer their questions in light of the previously mentioned ones.

Testing the first main hypothesis:

Ho.1: there is no statistically significant impact of the overall collective dimensions of complaints' handling on customers' satisfaction.

To test this hypothesis, the researcher computed the multiple linear regressions, as shown in the following table:

Table 9. The impact of overall complaints' handling on customers' satisfaction

\begin{tabular}{lcccc}
\hline Independent Variable & $\boldsymbol{\beta}$ & $\mathbf{T}$ & Sig & decision \\
\hline Complaints' handling & .784 & 24.645 & .000 & Reject \\
\hline
\end{tabular}

$\left(\mathrm{R}=.784 ; R^{2}=.614 ; \mathrm{F}=607.392\right) ; *$ significant level of $\mathrm{P} \leq 0.05$

Source: this table was developed based on the SPSS analysis.

Multiple regression was performed and the results in Table 9 showed that the impact of the overall dimensions of the complaints' handling on the customers' satisfaction was $(\mathrm{R}=78.4 \%)$, and the coefficient of determination $\left(\mathrm{R}^{2}\right)$ showed that the explained difference percentage in the customer satisfaction because of the impact of complaints' handling is not less than (61.4\%) of the total differences in customers' satisfaction and the remaining percentage is equal to (38.6\%) representing contribution percentage of the excluded variables that were not included in the study model as it shown in Table 9.

The value of computed ( $\mathrm{F}=607.392)$. In addition to significance level of (0.000).

This indicates that the curve of regression is good in explaining the impact of complaints' handling and customers' satisfaction.

The results of the simple regression analysis showed that there is positive impact of the overall complaints' handling on customers' satisfaction, $(\boldsymbol{\beta}=\mathbf{. 7 8 4})$ at level of significance $(0.000)$. Accordingly the researcher rejects 
the null hypothesis and accepts the alternative hypothesis which is:

There is a statistically significant impact of the overall dimensions of complaints' handling on customers' satisfaction.

\section{H0.1.1: there is no statistically significant impact of service recovery on customers' satisfaction.}

To test this hypothesis, the researcher computed the simple linear regression, as shown in the following table:

Table 10. The impact of Service recovery on customers' satisfaction

\begin{tabular}{lcccc}
\hline Independent Variable & $\boldsymbol{\beta}$ & $\mathbf{T}$ & Sig & Decision \\
\hline Service Recovery & .621 & 15.468 & .000 & Reject \\
\hline
\end{tabular}

$\left(\mathrm{R}=.621 ; R^{2}=.358 ; \mathrm{F}=239.269\right) ; *$ significant level of $\mathrm{P} \leq 0.05$

Source: this table was developed based on the SPSS analysis.

Simple regression was performed and the results in Table 10 showed that the impact of the service recovery on the customers' satisfaction was $(\mathrm{R}=62.1 \%)$, and the coefficient of determination $\left(\mathrm{R}^{2}\right)$ showed that the explained difference percentage in the customers' satisfaction because of the impact of complaints' handling is not less than $(35.8 \%)$ of the total differences in customers' satisfaction and the remaining percentage is equal to (64.2\%) representing contribution percentage of the excluded variables that were not included in the study model as it shown in Table 10.

The value of computed ( $\mathrm{F}=239.269)$.In addition to significance level of $(0.000)$.

This indicates that the curve of regression is good in explaining the impact of service recovery on customers' satisfaction

The results of the simple regression analysis showed that there is positive impact of the service recovery on customers' satisfaction, $(\boldsymbol{\beta}=\mathbf{. 6 2 1})$ at level of significance $(0.000)$. Accordingly the researcher rejects the null hypothesis and accepts the alternative hypothesis which is:

There is a statistically significant impact of service recovery on customers' satisfaction.

\section{H0.1.2: there is no statistically significant impact of service quality on customers' satisfaction.}

To test this hypothesis, the researcher computed the simple linear regression, as shown in the following table:

Table 11. The impact of service quality on customers' satisfaction

\begin{tabular}{lcccc}
\hline Independent Variable & $\boldsymbol{\beta}$ & $\mathbf{T}$ & Sig & Decision \\
\hline Service quality & .682 & 18.201 & .000 & Reject \\
\hline
\end{tabular}

$\left(\mathrm{R}=.682 ; R^{2}=.464 ; \mathrm{F}=331.286\right) ; *$ significant level of $\mathrm{P} \leq 0.05$

Source: this table was developed based on the SPSS analysis.

Simple regression was performed and the results in Table 11 showed that the impact of the service quality on the customers' satisfaction was $(R=68.2 \%)$, and the coefficient of determination $\left(R^{2}\right)$ showed that the explained difference percentage in the service quality because of the impact of complaints' handling is not less than (46.4\%) of the total differences in customers' satisfaction and the remaining percentage is equal to (53.6\%) representing contribution percentage of the excluded variables that were not included in the study model as it shown in Table 11.

The value of computed ( $\mathrm{F}=331.286)$. In addition to significance level of $(0.000)$.

This indicates that the curve of regression is good in explaining the impact of service quality on customers' satisfaction

The results of the simple regression analysis showed that there is positive impact of the service quality on customers' satisfaction, $(\boldsymbol{\beta}=\mathbf{. 6 8 2})$ at level of significance $(0.000)$. Accordingly the researcher rejects the null hypothesis and accepts the alternative hypothesis which is:

There is a statistically significant impact of service quality on customers' satisfaction. 


\section{H0.1.3: there is no statistically significant impact of switching cost on customers' satisfaction.}

To test this hypothesis, the researcher computed the simple linear regression, as shown in the following table:

Table 12. The impact of switching cost on customers' satisfaction

\begin{tabular}{lcclc}
\hline Independent Variable & $\boldsymbol{\beta}$ & $\mathbf{T}$ & Sig & Decision \\
\hline Switching cost & .238 & 4.779 & .000 & Reject \\
\hline
\end{tabular}

$\left(\mathrm{R}=.238 ; R^{2}=.056 ; \mathrm{F}=22.839\right) ; *$ significant level of $\mathrm{P} \leq 0.05$

Source: this table was developed based on the SPSS analysis.

Simple regression was performed and the results in Table 12 showed that the impact of the switching cost on the customers' satisfaction was $(\mathrm{R}=23.8 \%)$, and the coefficient of determination $\left(\mathrm{R}^{2}\right)$ showed that the explained difference percentage in the customers' satisfaction because of the impact of switching cost is not less than (5.6\%) of the total differences in customers' satisfaction and the remaining percentage is equal to (94.4\%) representing contribution percentage of the excluded variables that were not included in the study model as it shown in Table 12.

The value of computed ( $\mathrm{F}=22.839)$. In addition to significance level of (0.000).

This indicates that the curve of regression is good in explaining the impact of switching cost on customer satisfaction

The results of the simple regression analysis showed that there is positive impact of the switching cost on customers' satisfaction, $(\boldsymbol{\beta}=\mathbf{. 2 3 8})$ at level of significance $(0.000)$. Accordingly the researcher rejects the null hypothesis and accepts the alternative hypothesis which is:

There is no statistically significant impact of switching cost on customers' satisfaction.

\section{H0.1.4: there is no statistically significant impact of service failure on customers' satisfaction.}

To test this hypothesis, the researcher computed the simple linear regression, as shown in the following table:

Table 13. The impact of service failure on customers' satisfaction

\begin{tabular}{lcccc}
\hline Independent Variable & $\boldsymbol{\beta}$ & $\mathbf{T}$ & Sig & Decision \\
\hline Service failure & .546 & 12.733 & .000 & reject \\
\hline
\end{tabular}

$\left(\mathrm{R}=.546 ; R^{2}=.298 ; \mathrm{F}=162.118\right) ;{ }^{*}$ significant level of $\mathrm{P} \leq 0.05$

Source: this table was developed based on the SPSS analysis.

Simple regression was performed and the results in Table 13 showed that the impact of the service failure on the customers' satisfaction was $(\mathrm{R}=54.6 \%)$, and the coefficient of determination $\left(\mathrm{R}^{2}\right)$ showed that the explained difference percentage in the customers' satisfaction because of the impact of service failure is not less than $(29.8 \%)$ of the total differences in customers' satisfaction and the remaining percentage is equal to (70.2\%) representing contribution percentage of the excluded variables that were not included in the study model as it shown in Table 13.

The value of computed ( $\mathrm{F}=162.118)$. In addition to significance level of (0.000).

This indicates that the curve of regression is good in explaining the impact of service failure on customers' satisfaction

The results of the simple regression analysis showed that there is positive impact of the service failure on customers' satisfaction, $(\boldsymbol{\beta}=\mathbf{. 5 4 6})$ at level of significance $(0.000)$. Accordingly the researcher rejects the null hypothesis and accepts the alternative hypothesis which is:

There is a statistically significant impact of service failure on customers' satisfaction.

H0.1.5: there is no statistically significant impact of service guarantee on customers' satisfaction.

To test this hypothesis, the researcher computed the simple linear regression, as shown in the following table: 
Table 14. The impact of service guarantee on customers' satisfaction

\begin{tabular}{lcccc}
\hline Independent Variable & $\boldsymbol{\beta}$ & $\mathbf{T}$ & Sig & decision \\
\hline Service guarantee & .749 & 22.065 & .000 & reject \\
\hline
\end{tabular}

$\left(\mathrm{R}=.749 ; R^{2}=.560 ; \mathrm{F}=486.842\right) ; *$ significant level of $\mathrm{P} \leq 0.05$

Source: this table was developed based on the SPSS analysis.

Simple regression was performed and the results in Table 14 showed that the impact of the service guarantee on the customers' satisfaction was ( $R=74.9 \%)$, and the coefficient of determination $\left(\mathrm{R}^{2}\right)$ showed that the explained difference percentage in the customers' satisfaction because of the impact of service guarantee is not less than (56\%) of the total differences in customers' satisfaction and the remaining percentage is equal to (44\%) representing contribution percentage of the excluded variables that were not included in the study model as it shown in Table 14.

The value of computed ( $\mathrm{F}=486.842)$. In addition to significance level of (0.000).

This indicates that the curve of regression is good in explaining the impact of service guarantee and customer satisfaction.

The results of the simple regression analysis showed that there is positive impact of the service guarantee on customers' satisfaction, $(\boldsymbol{\beta}=\mathbf{. 7 4 9})$ at level of significance $(0.000)$. Accordingly the researcher rejects the null hypothesis and accepts the alternative hypothesis which is:

There is a statistically significant impact of service guarantee on customers' satisfaction.

\section{H0.1.6: there is no statistically significant impact of perceived value on customers' satisfaction.}

To test this hypothesis, the researcher computed the simple linear regression, as shown in the following table:

Table 15. The impact of perceived value on customers' satisfaction

\begin{tabular}{lcccc}
\hline Independent Variable & $\boldsymbol{\beta}$ & $\mathbf{T}$ & Sig & decision \\
\hline Perceived value & .710 & 19.715 & .000 & reject \\
\hline
\end{tabular}

$\left(\mathrm{R}=.710 ; R^{2}=.504 ; \mathrm{F}=388.682\right) ; *$ significant level of $\mathrm{P} \leq 0.05$

Source: this table was developed based on the SPSS analysis.

Simple regression was performed and the results in Table 15 showed that the impact of the perceived value on the customers' satisfaction was $(\mathrm{R}=71 \%)$, and the coefficient of determination $\left(\mathrm{R}^{2}\right)$ showed that the explained difference percentage in the customers' satisfaction because of the impact of perceived value is not less than (0.504) of the total differences in customers' satisfaction and the remaining percentage is equal to (49.6\%) representing contribution percentage of the excluded variables that were not included in the study model as it shown in Table 15.

The value of computed ( $\mathrm{F}=388.682)$. In addition to significance level of (0.000).

This indicates that the curve of regression is good in explaining the impact of perceived value on customers' satisfaction.

The results of the simple regression analysis showed that there is positive impact of the perceived value on customers' satisfaction, $(\boldsymbol{\beta}=\mathbf{. 7 1 0})$ at level of significance $(0.000)$. Accordingly the researcher rejects the null hypothesis and accepts the alternative hypothesis which is:

There is no statistically significant impact of perceived value on customers' satisfaction.

\section{Results Discussion and Recommendations}

\subsection{Results}

This chapter includes the discussion of the results, and based on the results, findings and discussions the researcher is suggesting some related recommendations. From the researchers' point of view and based on the results which shows a strong impact of the customer's complaints' handling on customers' satisfaction. The complaints' handling is very important because it provides information that can improve the service and is resolves issues of dissatisfaction. These results give us a picture of how is important these factors to such banks. 
From the study results, it showed that the means for the (Service Quality, Service Failure, and customer's satisfaction) domains were ranked High; with customer's satisfaction was the highest rank then the service Failure then the Service Quality.

In contrast, the results showed that both domains perceived value and service guarantee were at the lowest rank, but still moderate in the ranking degree scale.

The study has shown that all of the complaint handling factors(service recovery, service quality, switching cost, service failure, service guarantee and perceived value) have an affect on customers' satisfaction, and this finding is compatible with the study of (Johnston, 2001). The study results show that there is a statistically significant impact of the overall dimensions of complaint handling on the customer's satisfaction.

The study has shown that service recovery has an affect on customers' satisfaction, and this finding is consisted with the study of (Chuan et al., 2012) and also it's incompatible with the study of (Wu, 2011). The study results show that there is a statistically significant impact of service recovery on the customer's satisfaction.

Also the result of this study showed that service quality affect on customers' satisfaction, and this study is compatible with the finding of (Rahman et al., 2012) and also it's incompatible with the finding of (Wu, 2011). The study results show that there is a statistically significant impact of service quality and the customer's satisfaction.

For the switching cost, the result of this study showed that switching cost affects on customers' satisfaction, and this study is compatible with the study of (Lee, 2013). The study results show that there is a statistically significant impact of switching cost on the customers' satisfaction.

The study has shown that service failure affects on customers' satisfaction, and this study is compatible with the study of (Chuang et al., 2012). The study results show that there is a statistically significant impact of service failure on the customer's satisfaction.

The study has shown that service guarantee affects on customers' satisfaction, and this study is compatible with the study of (Kerr, 2004). The study results show that there is a statistically significant impact of service guarantee on the customer's satisfaction.

And finally the study has shown that perceived value affects on customers' satisfaction, and this study is compatible with the study of (Yang \& Peterson, 2004). The study results show that there is a statistically significant impact of perceived value on the customer's satisfaction.

\subsection{Recommendations}

Since all independent variables which are considered to be subsets of the main independent domain have positive significant impact on customers' satisfaction, and based on the study's findings and results as well discussion and implications in regards to the attitudes of customers toward their banks, the researcher suggest the following recommendations for the commercial banks in Jordan to pay more attention to the seriousness of the above variables or factors effect, and try to enhance all practices and related activities of which may decrease customers' complaints and strengthening the relationship with their customers through leveling up the quality of services provided to customers, and handling complaints in more effective way. In precise, many list the additional following recommendations:

1) The researcher recommends commercial banks in Jordan to respond effectively to banking services' failure which would reflect the service quality positively and therefore customers' satisfaction.

2) The researcher recommends commercial banks in Jordan to provide high service quality to their customers.

3) Commercial banks in Jordan are recommended to adopt more effective ways to enhance receiving complaints reliably.

4) Commercial banks in Jordan are recommended to open a special department for handling customers' complaints in order to increase customers' satisfaction.

5) And finally, the researcher recommend that some other related or of the same nature to be conducted on other businesses in the service industry in Jordan.

\section{Limitation of the Study}

The researcher has faced some limits classified as follows:

1) Human limits: represented by the clients of the commercial banks in Jordan.

2) Time limit: the academic year of 2013-2014. 
3) Place limits: commercial banks in Amman.

This research has only main limitation:

The difficulty which the researcher faced to seek the customers that faced problems with banking services provided by commercial banks in Jordan.

\section{References}

Aburoub, A. S., Hersh, A. M., \& Aladwan, K. (2011). Relationship between Internal Marketing and Service Quality with Customers' Satisfaction. International Journal of Marketing Studies, 3(2).

Allerd, A. T. (2001). Employee's Evaluations of Service Quality at Banks and Credit Unions. The International Journal of Banking, 19(4), 179-185.

Alshurideh, M., Masa'deh, R., \& Alkurdi, B. (2012). The Effect of Customer Satisfaction upon Customer Retention in the Jordanian Mobile Market: An Empirical Investigation. European Journal of Economics, Finance and Administrative Sciences, 47, 69-78.

Alvarez, I., Casielles, R., \& Martin, A. (2011). Analysis of The Role of Complaint Management in The Context of Relationship Marketing. Journal of Marketing Management, 27(1-2).

Berry, L. L., Valerie, A. Z., \& Parasuraman, A. (1990). Five Imperatives for Improving Service Quality. Sloan Management Review, Summer, 29-38.

Boshoff, C. (2012). Can Service Firms Overdo Service Recovery? An Assessment of Non-linearity in Service Recovery Satisfaction. S. Afr. J. Bus. Manage. 43.

Burnham, T. A., Frels, J. K., \& Mahajan, V. (2003). Consumer Switching Costs: A Typology, Antecedents, and Consequences. Journal of the Academy of Marketing Science, 31(2), 109-126. http://dx.doi.org/10.1177/0092070302250897

Chuang, S., Cheng, Y., Chang, C., \& Yang, W. (2012). The Effect of Service Failure Types and Service Recovery on Customer Satisfaction: A Mental Accounting Perspective. The Service Industries Journal, 32(2), 257-271. http://dx.doi.org/10.1080/02642069.2010.529435

Grewal, D., Monroe, K., \& Krishnan, R. (1998). The Effects of Price-comparison Advertising on Buyers' Perceptions of Acquisition Value. Journal of Marketing, 62(April), 46-59. http://dx.doi.org/10.2307/1252160

Gronroos, C. (1988). Service Quality: The Six Criteria of Good Perceived Service Quality. Review of Business, 9(1), 10-13.

Hasan, S., Raheem, S., \& Subhani, M. (2011). Measuring Customer Delight: A Model for Banking Industry. European Journal of Social Sciences, 22(4), 510-518.

Hays, J., \& Hills, A. (2006). An Extended Longitudinal Study of the Effects of a Service Guarantee. Production and Operations Management Society, 15(1).

Holbrook, M. B. (1994). The Nature of Customer Value: an Anthology of Services in the Consumption Experience. Service quality: new directions in theory and practice (pp. 21-71). Thousand Oaks, CA.

Johnson, R. (1995). Service Failure and Recovery: Impact, Attributes and Processes. Advances in Services Marketing and Management: Research and Practice, (4), 211-228. http://dx.doi.org/10.1016/S1067-5671(95)04025-0

Johnston, R. (2001). Linking Complaint Management to Profit. International Journal of Service Industry Management, 12(1), 60-69. http://dx.doi.org/10.1108/09564230110382772

Jones, M. A., Reynolds, K. E., Mothersbaugh, D. L., \& Beatty, S. E. (2007). The Positive and Negative Effects of Switching Costs on Relational Outcomes. Journal of Service Research, 9(4), 335-355. http://dx.doi.org/10.1177/1094670507299382

Kantamneni, S., \& Coulson, K. (1996). Measuring Perceived Value: Scale Development and Research Findings from a Consumer Survey. Journal of Marketing Management, 6(2), 72-86.

Kotler, P. (2000). Marketing Management (10th ed.). New Jersey: Prentice-Hall.

Kozub, K. A. (2008). The Effects of Service Recovery Satisfaction on Customer Loyalty and Future Behavioral Intentions. Unpublished dissertation, Auburn University.

Lee, H. (2013). Major Moderators Influencing the Relationships of Service Quality, Customer Satisfaction and 
Customer Loyalty. Asian Social Science, 9(2). http://dx.doi.org/10.5539/ass.v9n2p1

Lovelock, C., \& Wirtz, J. (2011). Services Marketing (7th ed.). Boston: Prentice Hall.

Malhotra, N. K. (2010). Marketing Research (6th ed.). New Jersey: Prentice Hall.

McCollough, M. (2009). The Recovery Paradox: The Effect of Recovery Performance and Service Failure Severity on Post-Recovery Customer Satisfaction. Academy of Marketing Studies Journal, 13(1).

McCollough, M. A., Berry, L. L., \& Yadav, M. S. (2000). An Empirical Investigation of Customer Satisfaction after Service Failure and Recovery. Journal of Service Research, 3(2), 121-137. http://dx.doi.org/10.1177/109467050032002

Meng, J., \& Elliott, K. (2007). Investigating Structural Relationships Between Service Quality, Switching Costs, and Customer Satisfaction. Journal of Applied Business and Economics.

Naser, K., Jamal, M., \& Al-Khatib, K. (1999). Islamic banking: a Study of Customer Satisfaction and Preferences in Jordan. International Journal of Bank Marketing, 17, 135-151. http://dx.doi.org/10.1108/02652329910269275

Parasuraman, A., Leonard, L. B., \& Valarie, A. Z. (1991). Understanding Customer Expectations of Service. Sloan Management Review, Spring, 39-48.

Rahman, M., Khan, A., \& Haque, M. (2012). A Conceptual Study on the Relationship between Service Quality towards Customer Satisfaction: Servqual and Gronroos's Model Perspective. Asian Social Science, 8(13). http://dx.doi.org/10.5539/ass.v8n13p201

Rothenberger, S., Grewal, D., \& Iyer, G. (2008). Understanding the Role of Complaint Handling on Consumer Loyalty In Service Relationships. Journal of Relationship Marketing, 7. http://dx.doi.org/10.1080/15332660802516029

Sadeh, E., Mousavi, L., Gargaz, M., \& Sadeh, S. (2011). The Structural Model of E-service Quality, E-customer Satisfaction, Trust, Customer Perceived Value and E-loyalty. Australian Journal of Basic and Applied Sciences, 5(3), 532-538.

Schiffman, L. G., \& Kanuk, L. L. (2007). Consumer behavior (9th ed.). New Jersey: Prentice Hall.

Sekaran, U., \& Bougie, R. (2009). Research Methods for Business A Skill-Building Approach (5th ed.). John Wiley and Sons.

Sheth, J. N., Newman, B. I., \& Gross, B. L. (1991). Why We Buy What We Buy: a Theory of Consumption Values. Journal of Business Research, 22(2), 159-170. http://dx.doi.org/10.1016/0148-2963(91)90050-8

Sunayana. (2013). Service Quality versus Customer Satisfaction in Banking Sector: A Literature Review. Journal of Marketing Management, 13(4).

Tax, S. S., Brawn, S., \& Chandrashekaran, M. (1998). Customer Evaluation of Service Complain Experiences: Implications For Relationship Marketing. Journal of Marketing, 62, 60-76. http://dx.doi.org/10.2307/1252161

$\mathrm{Wu}, \mathrm{K}$. (2011). Customer Loyalty Explained by Electronic Recovery Service Quality: Implications of the Customer Relationship Re-Establishment for Consumer Electronics E-Tailers. Contemporary Management Research, 7(1).

Yang, Z., \& Peterson, R. (2004). Customer Perceived Value, Satisfaction and Loyalty: The Role of Switching Cost. Psychology \& Marketing, 21, 99-822. http://dx.doi.org/10.1002/mar.20030

\section{Copyrights}

Copyright for this article is retained by the author(s), with first publication rights granted to the journal.

This is an open-access article distributed under the terms and conditions of the Creative Commons Attribution license (http://creativecommons.org/licenses/by/3.0/). 